\title{
Effect of Payments System Innovations on the Financial Performance of Commercial Banks in Nigeria
}

\author{
Zayyanu Mohammed* (1), Umar Abbas Ibrahim, Taiwo Adewale Muritala \\ Department of Business Administration, Nile University of Nigeria, Abuja, Nigeria \\ Email: *mmzayyan@gmail.com, abbas.ibrahim@nileuniversity.edu.ng, muritaiwo237@gmail.com
}

How to cite this paper: Mohammed, Z., Ibrahim, U. A., \& Muritala, T. A. (2022). Effect of Payments System Innovations on the Financial Performance of Commercial Banks in Nigeria. Journal of Service Science and Management, 15, 35-53.

https://doi.org/10.4236/jssm.2022.151004

Received: January 20, 2022

Accepted: February 19, 2022

Published: February 22, 2022

Copyright (C) 2022 by author(s) and Scientific Research Publishing Inc. This work is licensed under the Creative Commons Attribution International License (CC BY 4.0).

http://creativecommons.org/licenses/by/4.0/

\begin{abstract}
The study examines the effect of payments system innovations on the performance of commercial banks in Nigeria, Ex post factor research design was adopted for the study. The population of the study comprises all the banks operating in Nigeria. Data were collected from the economic reports and statistical bulletin of central bank of Nigeria. The Auto-Regressive Distributed Lags (ARDL) bounds approach to co-integration was adopted on quarterly time-series data from Q1 2007 to Q4 2020 to test the causal relationship between payments system innovations and financial performance of commercial banks in Nigeria. The results indicated that mobile payment, POS transactions and internet payment have positive and significant impact on return on assets of commercial banks in Nigeria, while RTGS has negative impact on the return of assets. The results of the study will fill the knowledge gap and will benefit both regulators and operators in making decision-making process and development of new policies that will aid the promotion of innovative products for safe reliable, and credible payments system and in identify payments system technology, projects and initiatives that are significantly viable, respectively. The study recommends the need for the commercial banks in Nigeria to undertake massive mass media enlightenment campaigns on all payments system innovations/initiatives.
\end{abstract}

\section{Keywords}

Real Time Gross Settlement, Mobile Payment, Point-of-Sale Terminal, Internet Payment and Return on Assets

\section{Introduction}

Banking is a sector that advocates technological innovations and monitored them 
closely and used widespread (Suleymanov et al., 2019). The industry is based on efficient service delivery and it is always vital to introduce various products/services to fast-track this process (Lin, 2007; Tasaki \& Yamakawa, 2011; Yao et al., 2018). With the advent of e-commerce globally, new information technologies, especially payment system innovations have changed modern commercial activities (Guo \& Liang, 2016).

In recent decades, commercial banks' investment in payments system technologies has aided to simplify operations, improve competitiveness, and enhance the variety and service quality rendered by the banks (Salehi \& Alipour, 2014). This technology-based payments system contributed immensely to enhance the convenience of bank's customers, the staff and the general public (Kelvin, 2012).

It is generally recognized that a well-functioning payment infrastructure is critical to the increase of efficiency of the banking sector, financial markets, and the financial system, it also boosts consumer's confidence, eases economic cooperation and trade (Bank for International Settlement [BIS], 2006; European Central Banks [ECB], 2010). A payments system that is not secured may obstruct the smooth movement of funds between individuals and economic players (Humphrey et al., 2006).

Most recently, the Corvid-19 pandemic has boasted the use of digitalized payments system and made a striking impact on electronic payments (BIS, 2021). Specifically, the total value of e-payment or digital credit payment grew remarkably in developed economies, emerging market as well as the developing countries. These e-payments include online payment, mobile payment, web transfer (BIS, 2021). The pandemic has also, encouraged the effort of many central banks in developing central banks digital currencies (BIS, 2021).

Nigerian economy is historically cash-driven, most especially in the consumer sector, however, for most of the past two decades, The Central Bank of Nigeria (CBN) and the commercial banks have been at the front of adopting the use of payments system innovations in the banking business, which has significantly moved the payments ecosystem from the early days of banking operations to the present state of digitalization in comparison with other developing economies. This is for the most part tracked by the increased use of payments system technology in the country (Bingilar \& Bariweni, 2019).

Payments system technology products provide opportunity to banks to have momentous cost advantage, enhancing profitability, ease of processing and minimize risk than traditional banking system (Akhisar et al., 2015). Despite enormous advantage associated with payments system innovations in Nigeria, it is not in place without some challenges such as infrastructure deficit, high level of financial illiteracy, low level and high cost of internet access (Nwakoby et al., 2020; CBN, 2013).

There are conflicting results about the effect of payments system innovations on the financial performance of commercial banks. Several studies revealed the positive impact of payments system on the financial performance/profitability of 
banks: Dong et al. (2020); Okafor (2020); Shahabi and Razi (2019); Abaenewe et al. (2013). Similarly, other studies highlighted mixed results of the positive impact by some of the proxies of payments system channels and negative impact by some other channels on performance of commercial banks/financial institutions. These include the research work of Shanmugam and Nigam, (2020); Bingilar and Bariweni (2019). However, the studies of Nwankwo and Eze (2013); Onay and Ozsor (2013); Saeed and Bampton (2013); indicted no influence of payments system technology or revealed a negative effect on the financial performance of the commercial banks.

Moreover, another significant flaws of the existing studies are, majority of the empirical were using annual data averaged five years or less than ten years, and some other using few banks or data of only one bank in their analysis, which were grossly inadequate to examine long term relationship between payments system technology and financial performance of commercial banks and makes reliable findings and conclusion, as some critical data or information were lost or not captured in the analysis. Therefore, the striking difference of this study from other empirical studies on this area, is the use of industry quarterly data of all the commercial banks operating in Nigeria from Q1 2007 to Q4 2020 to investigate the effect of payments system innovations proxied by RTGS, mobile payments, POS transactions and internet payment on the financial performance of commercial banks in Nigeria proxied by return on assets.

\section{Literature Review}

The banking system is the most obvious financial intermediation provider throughout the world. A combination of banking and payments system technology transforms the world. With the prompt increase in the use of the internet and adoption of other payment system technology, a drastic change is witnessed in the banking practices from traditional banking to online banking (Kamboh \& Leghari, 2016).

Payment systems comprise active linkage governed by-laws, rules, and principles which link bank accounts and provides the necessary functionality of monetary exchange using bank deposits. It is the arrangement comprising of institutions, establishments, instruments, rules, standards, procedures, and technical processes recognized to make possible fund transfer between different parties discharging agreed obligations (Summers, 2012; Bingilar \& Bariweni, 2019).

An efficient payments system makes transaction cost less expensive and is essential to the effective operation of third party transfer, interbank and security payments. A weak payments system may rigorously encumbrance on the solidity and evolving capacity of the economy; its unreliability can lead to wasteful use of economic resources, unbalanced risk-sharing among agents, and loss of public confidence in the banking system (Cirasino \& Garcia, 2008).

Payment systems have been the object of several policy deliberations and scholarly studies. Conventionally this was for the assessment of their efficiency and the influence they could bear on financial stability as well as the stability of 
markets in general. Certainly, the debate has produced various international standards with the specific goal of ensuring their smooth functioning as critical to the overall efficiency and stability. Also, central banks over the world have developed autonomous functions, and most of them created a specific department of payments system oversight within their operational structure (Malaguti, 2015).

In this context, The World Bank during the last two decades has been supporting many countries in providing critical infrastructure that improve their national payment systems, and established collaboration and cooperation with various stakeholders, and providing a lot of financing, and technical knowledge. The World Bank in 2007 dispatched the Global Payments System Survey (GPSS), to gather data on the status of payments system around the world. From that point forward, the GPSS has permitted specialists and policymakers to make suggestive cross-country appraisals and assess progress in payments system improvement, and that has encouraged the dispersal of best practices (WBG, 2018).

Innovation in technology and specifically payments system innovations have given credibility to the revolution of the operational aspect of banking globally since the turn of the millennium. The automation of banks makes payment and settlement of transactions very easily adaptable for quick management decision making. This led to another level of benefit which steered in what is today referred to as electronic payments. Specifically, commercial banks in Nigeria identified electronic payment as a very effective platform and have used it properly in recent times to improve their performance and profitability (Mesagan \& Amadi, 2016; Yusuf et al., 2019).

There are several measurable variables for payment system innovations, though Real-Time Gross Settlement, mobile payments, POS transactions, and Internet payments were used for this study as they comprise both the retail and wholesale components of payments system. In addition, they are the most developed payments system technology in Nigeria and the most widely used by researcher as proxies of payments system (Akwam \& Yua, 2021; Nwankwo \& Agbo, 2021; Tran, 2021; Nwakoby et al., 2020; Okafor, 2020; Muotolu \& Nwadiafor, 2019; Zu et al., 2019).

\subsection{Real-Time Gross Settlement (RTGS)}

RTGS is an electronic platform that facilitates the transaction of large-value payments between commercial banks and third parties on a real-time online basis. Transactions on this platform are done on an individual and gross basis. The system offers several benefits which include reduction of systemic risk, elimination of settlement risk as payment message is irrevocable and effective means of monetary policy implementation. The system also is capable of providing Delivery Vs Payments (DVP) for securities settlement and Payments Vs payments (PVP) for foreign exchange settlement to reduce their risks. Real-Time Gross Settlement System is crucial to financial system stability because the whole financial system relies on it, thus system downtime poses a serious systemic risk as 
it would obstruct economy-wide transactions. The Nigerian RTGS system is currently known as the Nigerian Settlement System (NISS).

\subsection{Mobile Payments}

Mobile payment is any electronic means of carrying out a payment in which a mobile device, for example, a cell phone, tablet, fixed remote telephones is utilized to start, approve and additionally affirm an exchange of monetary incentive as a trade-off for merchandise and ventures (Taylor, 2013).

Mobile payment has many categories, but the machinery to convey it can be classified into two categories, remote m-payments and proximity payments (Agarwal et al., 2007). The remote payments require customers' registration, usually comprising the download of an application, and then use it on their mobile device to pay for items. Customers may choose to have a prepaid card with a value stored on it or directly pull funds from a bank account. Payment service providers (PSPs), for example, Google, PayPal utilize a cloud-based far off way to deal with in-store portable installment. Then again, nearness payment requires the client to introduce a credit card, cell phone or tablet gadget at a payment terminal to finish the exchange.

In Nigeria, there are two models of mobile payment permitted in the mobile framework, the Bank Led with Licensed Deposit-Taking Financial Institutions as lead initiator and Non-Bank Led, where a corporate organization other than licensed deposit-taking institutions and telecommunication companies serve as lead initiator. But Telco led are not allowed (CBN, 2017).

\subsection{Point of Sale Terminal}

An electronic point of sales terminal of payment system is used for instant payment of goods and services, the terminal is user-friendly, simple to operate, and has multi-functional equipment with many possibilities of use. It enables the operators to receive and transmit payments to/from customer account in a simple way and subsequently to record the payments for proper accounting purposes. Evidence from the literature shows that 28 billion transactions are made using POS systems in North America. Also in the United States, there are over 10 million POS terminals; (Morufu, 2016).

The use of POS terminal has significantly reduced the use of cash-based transactions. Ayodele (2014) described point of sale as a channel that allows cardholders makes payments at sales or purchase outlets. It permits customers to make services inquiry, airtime purchases, vending, loyalty, redemption, and printing of mini statements (Osang, 2017). The advantages of using the terminal include ease of payments, convenience, and security.

\subsection{Internet Payment}

This is a type of electronic payment which enable customer of a financial institution to carry out financial transactions where customers' instructions are taken 
and attended to through the internet. Web payment offers clients the chance of getting banking services from the solace of their homes and workplaces. Clients can purchase merchandise by putting orders from the net, direct their banks to pay the seller the receipt sum included, and the items are conveyed to the place where the purchaser needs them (Abaenewe et al., 2013).

The internet is an innovative form of information technology, yet most commercial web sites function as well-defined information systems. Internet banking, compared to the traditional banking system, heavily involves no-human contacts between customers and banking information systems. This means that the satisfactory delivery of service not only relies on the traditional service quality identified in existing literature but also on a reliable online system to provide a comfortable end-user computing environment. Therefore, internet payment has contributed to making the Nigerian payments system, robust, convenient, and accessible.

The study adopts three theories and models to support the research work namely: Innovation Diffusion Theory, Technology Acceptance Model, and the chocolate model. The innovation Diffusion Theory identified five attributes that affect whether an innovation is adopted or not, namely: relative advantage, compatibility, complexity, trialability, and observability and accordingly, the theory argued that the spread of new ideas in an organization is informed by social systems, time, channels of communication and innovation itself (Rogers, 1962). The Technology Acceptance Model centers around two ideas on how the advancement is seen by the potential adopter identified with its convenience and its likely helpfulness. The hypothesis takes a glance at how much the development will improve the client's close personal or occupation related performance (Straub, 2009). It contended that it would not make any difference how simple innovation is to learn; individuals would not adopt it on the off chance if they didn't see it to be helpful in expanding their efficiency (Davis, 1989). While the Chocolate Model focuses on innovation adoption and change related to an organization. It is designed around change, adopters, the change agents, and the organization. The theory looks at the relative advantage of the innovation or change, and on what the change will mean for the social structure and climate of the organization (Dormant, 2011).

Although, any of the three theory could be utilized for this study, Innovation Diffusion Theory is found most appealing in underpinning what the study attempts to achieve, largely due to the theory's approach in identified four elements of innovation, time, communication channels, and the social framework that boast the spread of technological innovations as indicated by in the works of Dillon the Moris (1996) and Rogers (1983, 2003). Similarly, these elements are crucial and vital to commercial banks on any successful implementation of payments system technology project.

There are many studies undertaken on this area. Several studies show the impact of payments system innovations on the performance of banks. Suleymanov et al. (2019) looking at cross-country pane data, examined the effects of elec- 
tronic payments innovations on bank performance using dynamic panel data as a method of analysis on data from 23 developed and developing countries ranging from 2008-2018. The study discovered that all payments system channels in the study impact on the profitability, apart from POS and internet services who affected profitability negatively. Also, Akhisar et al. (2015) investigate the impact of electronic payment innovations on bank performance using data from 23 developed and developing countries for the period 2005-2013. The findings revealed that payment innovations affect profitability positively except for POS and internet payment which affect profitability negatively.

Tunay et al. (2015) in their research work on effect of internet payment on the performance of banks in Europe, adopting a panel causality tests approach to examines the impact of internet payments and bank profitability of a member of the European Union and non-European of 30 countries discovered that more advanced internet banking practices in European countries illustrate the more performance of the strongest banks.

From the emerging economy of China, Yao et al. (2018) investigate the impact of payment technology on the financial performance of the banking sector of China, using the Vector Auto-Regression impulse model to analyzed Third-Party Payment (TPP) data ranging from 2007 to 2014. The findings revealed that TPP increases money turnover and positively affect the financial sector earning growth. Hence, the results empirically indicate that innovations of payment technology contribute to industry synergist in the evolution of the financial industry in China. Also, Dong et al. (2020) look at the effect of web finance on commercial bank's performance in China. The paper inventively utilizes multi-source information to fabricate a web account list, which contains Internet search information and Internet monetary exchange information. The outcomes show that the improvement of Internet finance decidedly affects the benefit, security, and development of banks, hence, contrarily affects their liquidity. The investigation likewise indicated that web finance has advanced the enhancement of the thorough business execution of banks in China.

In India, Vikram and Gayathri (2018) investigate the effect of information technology on the financial performance of banks in India, employing panel data consisting of cross-sectional and time-series data of 21 banks for the period 2011-2015, discovered that investment in IT increases profitability for banks. Kamboh and Lighari (2016) undertake a study on the effect of cashless payments system on the financial performance of the Pakistani banking industry, using OLS regressions analysis on quarterly data from Q2, 2007 to Q4, 2014 and the results indicated that that POS transaction and Mobile payment are positively significantly correlated to ROE, while ATM transactions are negatively, significantly, related with profitability. This finding is in contrast with that of $\mathrm{Zu}$ et al. (2019) who discovered in their studies on Impacts of payments system technology on the performance evidence of electronic banking in Africa adopting descriptive research design and panel regression model that ATM affects banks profitability positively, while POS and internet payments affect profitability negatively. 
From the Sub-Saharan African country of Cameroun, Anselm Ngwa (2020) in his study on electronic banking transactions and their effect on financial performance of some selected commercial banks in Cameroon, using econometric techniques of descriptive analysis, and adopting regression analysis on quarterly data of 4 commercial banks from 2012-2018 to examines the effect of mobile payment, ATM, prepaid cards (PPV), and DTF on return on assets of banks. The findings revealed that mobile money transfer, Domestic Transfer Fund equivalent of RTGS transaction and Electronic Point Terminal via all have positive impacts on return on assets, however Prepaid cards such as ATM. Debit cards have negative impacts on the return on assets of the banks. Specifically, the overall finding indicated that e-payment transactions have significant effect on the financial performance of banks in Cameron.

While in Kenya, Vekya (2017) adopting a descriptive research design on data from 43 commercial banks to investigate the impact of electronic banking on the financial performance of banks in Kenya, established positive significant relationship between ATM transactions and bank profitability. This finding corroborated with Muisyo et al. (2014) findings on their study on the impact of mobile payment on the financial performance of banks in Kakamega Town of Kenya, which revealed that mobile payments have contributed positively to the performance of banking institutions. Similarly, Cherotich et al. (2015) conducted a study on the impact of payments system innovations on the financial performance of banks in Kenya, using a secondary data of a five-year period from 2009 to 2015 from a population of 43 commercials banks operating in Kenya as at End-December, 2013. The findings revealed that financial performance proxies by electronic fund transfers (EFTs), cheque and RTGS revealed a positive impact on return on equity of commercial banks in Kenya.

In Nigeria, some researchers have examined the payments system technology and the commercial banks' performance relationship. For instance, Frank and Binaebi (2019) examined the impact of electronic payments system implementation on the financial performance of Nigerian's commercial banks. The research uses annual data ranging from 2009 to 2018 and adopts the ordinary least square regression technique. Four measures of payments system technology namely, ATM transactions, POS transactions, internet payments, and mobile payments were used with aggregated asset base used as the measure of performance of commercial banks. The empirical results of the study provided that an implementation of payments system innovations has had a mixed effect on the financial performance of banks in Nigeria. ATM, internet payment, and mobile payments have a positive effect on the financial performance of banks, while POS terminals have a negative effect on the bank performance.

On the same pattern of investigation, Orji et al. (2018) in their study on electronic banking innovations and some selected banks in Nigeria using a SURE model to analyzed data from six selected banks in Nigeria ranging from 20072016 revealed that ATM, POS, mobile payment and bank size have positive and significant effect on the banks' financial performance. 
Also, Nwakoby et al. (2020) examined the effects of electronic payments on the performance of 9 selected banks out of 15 quoted in the Nigerian stock exchange. The research work implemented the OLS regression technique of analysis using ATM transactions, POS transactions, and mobile payments as measures of electronic banking with return on equity as a measure of banks' profitability. The findings revealed that ATM transactions have a negative effect on return on equity of DMBs. While both POS and mobile payment has a positive impact on return on equity of DMBs in Nigeria.

However, Akwam and Yua (2021) conducted research on effects of e-money products on the financial performance of some commercial banks in Nigeria using volume of POS, mobile payments and ATM transactions as proxies of financial products and return on assets, return on equity and earning per share as proxies of banks performance. A time series annual data from 2005-2019 of mobile payment, POS and ATM were employed to determined their impact on ROA, ROE and earnings per share, respectively. The findings revealed that Mobile payment and POS have significant positive effect on ROA and ROE, respectively. Also, ATM transactions have significant positive effect on earnings per share.

The above results corroborated with the findings of Muotolu and Nwadialor (2019) in their studies on cashless policy in Nigeria and its impact on the financial performance of commercial banks, using volumes of ATM, POS, internet payment, NEFT and NIP as proxies of cashless policy, and return on asset as proxy of bank performance. The research work adopts a panel data from 14 banks ranging from 2012 to 2017, which were analyzed using descriptive statistic, multicollinearity test, correlation testing, and heteroscedasticity testing. The findings indicated that volume of ATM transactions has significant positive impact on ROA of banks in Nigeria, however, Volume POS, internet, NEFT and NIP have insignificant positive impact on ROA of banks in Nigeria.

From the findings of the above empirical studies on the impact of payments system innovations on the performance of commercial banks, the results are inconsistent and in some cases contradictory, due largely to inadequate data and the methodology adopted. Therefore, this study seeks to investigate the effect of payments system innovations on the financial performance of commercial banks in Nigeria using quarterly data from Q1 2007 to Q4 2020 obtained from economic reports and statistical bulletin of central bank of Nigeria.

\section{Methodology}

The present study has chosen to conduct this research according to the postpositivist philosophy advocated "from the work of nineteenth century writers such as Comte, Mill, Durkheim, Newton and most recently from the effort of Phillips and Burbules (2000)", who beliefs that causes determine effect or outcome, Thus, the problem studies by postpositivist reflect the need to identify and asses the cause that influence outcomes (Mertens, 2019; Creswell \& Creswell, 2018). 
This study is driven by the ontological assumptions that empirical reality is objective and is external to the subject. This is in ten den with the view of Ahrens and Chapman (2006), who emphasizes that ontological stance assumes the existence of an objective reality. It is also, in line with epistemological assumption that phenomena "can be studied through objective categories and verified by empirical scientific method" (Ahrens \& Chapman, 2006).

Ex post factor research design has been adopted for the study. According to Kerlinger (1986), this design is a kind in which the independent variable or variables have already occurred where the researcher begins the observation of a dependent variable or variables and then studied the independent variables in reconsideration for their possible relation to and effects on the dependent variables. So ex-post factor design is appropriate for collecting and summarizing the data in the study and seeks to explore the relationship between the independent variables of payments system innovations proxied by RTGS transactions, mobile payments, POS transactions and internet payment with dependent variable of financial performance of commercial banks proxied by return on asset and control variable of banking system credit to the economy. The population of the study comprises all the 24 commercial banks operating in Nigeria at End-December, 2020. A convenient sampling technique was adopted, in which case the contribution of all commercial banks from 2007-2020 were taken into consideration.

\subsection{Method of Data Analysis}

The explanatory descriptive analysis was carried out using descriptive statistical tools such as mean, median, standard deviation, skewness, etc. Jarque-Bera method was used to test the normality of the data. In testing stationarity, Augmented Dickey Fuller (ADF) test was employed to detect presence of unit root in the data, also chow breakpoint test and Bai-Perron multiple breakpoint were used to test for single and multiple structural break, respectively. The Auto-Regressive Distributed Lags (ARDL) bounds approach to co-integration was adopted on quarterly time-series data from Q1 2007 to Q4 2020 to test the causal relationship between payments system innovations and financial performance of commercial banks in Nigeria.

\subsection{Model of Specification}

The study adopts Ibrahim and Mohammed (2020), specifying a model of Auto-Regressive Distributed Lags (ARDL) bounds approach to cointegration in measuring the effect of Payment System Technology (PST) on Performance of Commercial Banks (PCB). Therefore, the model is given as:

$$
\begin{aligned}
& D\left(R O A_{t}\right)=\beta_{01}+\beta_{11}\left(R O A_{t-1}\right)+\beta_{21}\left(R T G S_{t-1}\right)+\sum_{i=0}^{p} \alpha_{1 i} D\left(R O A_{t-1}\right) \\
& +\sum_{i=0}^{q} \alpha_{2 i} D\left(R T G S_{t-1}\right)+\beta_{31}\left(V M P_{t-1}\right)+\sum_{i=0}^{q} \alpha_{3 i} D\left(V M P_{t-1}\right) \\
& +\beta_{41}\left(P S_{t-1}\right)+\sum_{i=0}^{q} \alpha_{4 i} D\left(P O_{t-1}\right)+\beta_{51}\left(V_{T I} P_{t-1}\right) \\
& +\sum_{i=0}^{q} \alpha_{5 i} D\left(V I P_{t-1}\right)+\beta_{61}\left(B S C_{t-1}\right)+\sum_{i=0}^{q} \alpha_{6 i} D\left(B S C_{t-1}\right)+\varepsilon_{i t}
\end{aligned}
$$


where $\alpha_{i j}$ and $\beta_{i j}$ are the coefficients measuring the impact of each payments system technology on ROA. Also, $R O A_{t}$ denotes return on asset at time $t, R T G S_{t}$ Real-Time Gross Settlement transactions at $t, V M P_{t}$ volume of mobile payment at time $t, P O S_{t}$ point of sale transaction at time $t, V I P_{t}$ Volume of internet payment at time $t$ and $B S C_{t}$ banking system credit at time $t$.

\subsection{Descriptive Statistics}

The summary of the statistical results in Table 1 below, indicated that the mean Return on Asset (ROA) is 0.02 with standard deviation of 0.02 , the ROA ranges from -0.09 to 0.07 . The highest ROA was observed at the second, third and fourth quarter of year 2007 respectively, while the lowest ROA was recorded at fourth quarter of the year 2009. Both variables follow normal distribution with non-significant Jarque-Bera value. Also, the Kurtosis of the variables fell within benchmark of 3 for standard normal distribution. The lower the value, the flatter the peak.

\section{Unit Root Test}

The original data of ROA and volume of internet payments was stationary at level with $\mathrm{p}$ value of Augmented Dickey Fuller (ADF) which is less than level of significant. The variation in the series is constant at level. Integrated of order zero $\mathrm{I}(0)$. While other variable were integrated at order $\mathrm{I}(0)$.

\begin{tabular}{cccc}
\hline & T-Statistic & P-value & Integrated order \\
\hline ROA & -3.95 & 0.003 & $\mathrm{I}(0)$ \\
RTGS & -8.21 & $<0.0001$ & $\mathrm{I}(1)$ \\
MOBILE & -10.31 & $<0.0001$ & $\mathrm{I}(1)$ \\
POS & -9.23 & $<0.0001$ & $\mathrm{I}(1)$ \\
INTERNET & -4.50 & 0.0006 & $\mathrm{I}(0)$ \\
BSC & -7.03 & $<0.0001$ & $\mathrm{I}(1)$ \\
\hline
\end{tabular}

\subsection{Bound Test}

The Bounds test check if the null hypothesis of no long-run relationship exists. Table 2 below shows the result for the ROA model that Bounds test is significant due to high value of the F-statistic (6.44) which indicates that long run relationship do exist.

\subsection{Long Run Relationship}

The long run relationship shows in the Table 3 below depicts that a unit increase in mobile payments will bring a corresponding increase of 1.016 percent in ROA at long run and significant. Also, volume of Point-of-Sale (POS) transactions and internet payment will increase ROA by 1.025 and 1.1 percent, respectively and were significant. Banking system credit has positive impact on ROA at the long run but not significant at 0.05 level. This result implies that mobile pay- 
ment, volume of Point-of-Sale (POS) transactions and volume of internet payment have significant effects on Return on Assets of commercial banks in Nigeria.

Table 1. Descriptive statistics.

\begin{tabular}{ccccccc}
\hline & ROA & LRTG & LMOB & LPOS & LIN & LBSC \\
\hline Mean & 0.02 & 11.54311 & 14.98246 & 15.03969 & 14.64464 & 16.38624 \\
Median & 0.02 & 11.69152 & 15.44284 & 15.20373 & 13.92450 & 16.56119 \\
Maximum & -0.09 & 12.73616 & 18.88708 & 19.18545 & 21.52412 & 17.56629 \\
Minimum & 0.07 & 9.502039 & 11.15781 & 10.93594 & 11.87440 & 13.19991 \\
Std. Dev. & 0.02 & 0.950208 & 2.178141 & 2.510639 & 2.314522 & 0.941491 \\
Skewness & 0.594 & -0.57 & 0.011362 & 0.124954 & 1.549112 & -0.30 \\
Kurtosis & 3.14 & 2.159959 & 1.855176 & 1.616156 & 5.043369 & 2.727758 \\
\hline
\end{tabular}

Table 2. ARDL bound test.

ARDL Bounds Test

Date: 11/17/21 Time: 11:36

Sample: 2008Q1 2020Q4

Included observations: 52

Null Hypothesis: No long-run relationships exist

\begin{tabular}{ccc}
\hline Test Statistic & Value & $\mathrm{k}$ \\
F-statistic & 6.439947 & 5 \\
\hline & Critical Value Bounds & \\
\hline Significance & I0 Bound & I1 Bound \\
\hline $10 \%$ & 2.26 & 3.35 \\
$5 \%$ & 2.62 & 3.79 \\
$1 \%$ & 2.96 & 4.18 \\
\hline
\end{tabular}

Table 3. Long run relationship model.

\begin{tabular}{ccccc}
\hline \multicolumn{5}{c}{ Long Run Coefficients } \\
\hline Variable & Coefficient & Std. Error & t-Statistic & Prob. \\
\hline LRTG & -0.000103 & 0.007113 & -0.014548 & 0.9885 \\
LINT & 0.095966 & 0.031894 & 3.008862 & 0.0046 \\
LMOB & 0.015580 & 0.004116 & 3.789413 & 0.0014 \\
LPOS & 0.024353 & 0.007056 & 3.436881 & 0.0031 \\
LBA & 0.012695 & 0.022142 & 0.573365 & 0.5702 \\
C & -0.176167 & 0.256781 & -0.686060 & 0.4973 \\
\hline
\end{tabular}




\subsection{Error Correction Model}

From Table 4 below the ECM coefficient is the CointEq(-1) form the ECM table. The term, CointEq $(-1)$, is -0.714 and highly significant $(p<0.0001)$. the negative value indicates long run convergence among the variables in the model and previous error will be corrected in the current period with the speed of adjustment of $71 \%$. The result shows that mobile payments and POS are significant at the long run.

\subsection{Autocorrelation and Heteroscedasticity}

Table 5 below shows autocorrelation or residual serial correlation using BreuschGodfrey serial correlation Lagrange Multiplier (LM) test was not significant which implies that, there was no serial correlation in the residuals of the model. Also, Heteroscedasticity of the residual using Breusch-Pagan-Godfrey test was not significant which implies that, the variance of the residuals is homoscedasticity.

Table 4. Error correction model.

\begin{tabular}{|c|c|c|c|c|}
\hline \multicolumn{5}{|c|}{ ARDL Cointegrating And Long Run Form } \\
\hline \multicolumn{5}{|c|}{ Dependent Variable: NROA } \\
\hline \multicolumn{5}{|c|}{ Selected Model: ARDL(1, 0, 0, 4, 3, 4) } \\
\hline \multicolumn{5}{|c|}{ Date: $11 / 17 / 21$ Time: $11: 39$} \\
\hline \multicolumn{5}{|c|}{ Sample: 2007Q1 2020Q4 } \\
\hline \multicolumn{5}{|c|}{ Included observations: 52} \\
\hline \multicolumn{5}{|c|}{ Cointegrating Form } \\
\hline Variable & Coefficient & Std. Error & $\mathrm{t}$-Statistic & Prob. \\
\hline D(LRTG) & -0.000074 & 0.005074 & -0.014563 & 0.9885 \\
\hline $\mathrm{D}(\mathrm{LINT})$ & -0.001694 & 0.002758 & -0.614264 & 0.5431 \\
\hline $\mathrm{D}(\mathrm{LMOB})$ & 0.005500 & 0.007636 & 0.720340 & 0.4762 \\
\hline $\mathrm{D}(\operatorname{LMOB}(-1))$ & 0.027290 & 0.010985 & 2.484425 & 0.0181 \\
\hline $\mathrm{D}(\operatorname{LMOB}(-2))$ & -0.021221 & 0.010100 & -2.101181 & 0.0431 \\
\hline $\mathrm{D}(\operatorname{LMOB}(-3))$ & 0.010000 & 0.005563 & 1.797669 & 0.0811 \\
\hline $\mathrm{D}(\mathrm{LPOS})$ & -0.010141 & 0.009633 & -1.052750 & 0.2999 \\
\hline $\mathrm{D}(\operatorname{LPOS}(-1))$ & -0.032104 & 0.011509 & -2.789413 & 0.0086 \\
\hline $\mathrm{D}(\operatorname{LPOS}(-2))$ & 0.018114 & 0.009341 & 1.939094 & 0.0608 \\
\hline $\mathrm{D}(\mathrm{LBA})$ & -0.034389 & 0.036396 & -0.944856 & 0.3514 \\
\hline $\mathrm{D}(\operatorname{LBA}(-1))$ & -0.083037 & 0.044759 & -1.855189 & 0.0723 \\
\hline $\mathrm{D}(\operatorname{LBA}(-2))$ & -0.060638 & 0.043385 & -1.397674 & 0.1713 \\
\hline $\mathrm{D}(\mathrm{LBA}(-3))$ & 0.076393 & 0.024755 & 3.086025 & 0.0040 \\
\hline CointEq(-1) & -0.714129 & 0.153003 & -4.667429 & 0.0000 \\
\hline
\end{tabular}


Table 5. Breusch-Godfrey serial correlation LM test and heteroscedasticity test: BreuschPagan-Godfrey:

\begin{tabular}{cccc}
\hline F-statistic & 0.163735 & Prob. F(2.32) & 0.8495 \\
Obs $^{\star}$ R-squared & 0.370343 & Prob. Chi-Square(2) & 0.8310 \\
F-statistic & 1.603725 & Prob. F(17.34) & 0.1181 \\
Obs ${ }^{\star}$ R-squared & 23.14097 & Prob. Chi-Square(17) & 0.1447 \\
Scaled explained SS & 21.62019 & Prob. Chi-Square(17) & 0.1998 \\
\hline
\end{tabular}

\subsection{Normality Test}

The descriptive statistics of the residual below shows that the mean is close to zero and standard deviation of 0.269 , the kurtosis of 3.08 and coefficient of skewness is -0.42 . The Jarque-Bera test statistic indicates that the residual is normally distributed.

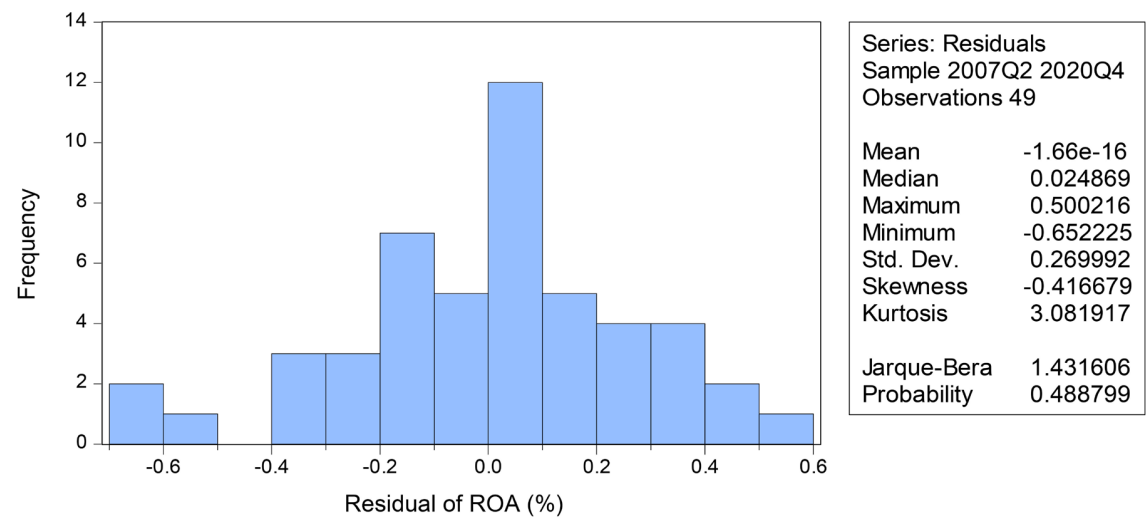

\section{Interpretation of Results}

The results of the finding of the null hypothesis one as indicted in the ARDL bound test Table 2 and long run relationship Table 3 above indicated that in the long run volume of real-time gross settlement transactions has negative impact on return on assets of the commercial bank in Nigeria, hence the null hypothesis that volume of RTGS transactions has no significant impact on return on assets of commercial banks in Nigeria cannot be rejected. This collaborates with the findings of Vijayalakshmi and Jayalakshmi (2019) that RTGS has negative impact with operating profit of some selected banks in India. However, it is in contrast to the findings of Muhoro and Mungai, 2018; Boateng and Nagaraju, (2020) that RTGS has positive and significant impact on the return on assets of commercial banks.

The finding of the null hypothesis two that volume of mobile payment has no significant impact on return on assets of commercial banks in Nigeria was also rejected based on the findings of this study as indicated in the bound test Table 2 and long run relationship model Table 3 that long run relationship do exist and that mobile payment have significant positive effect on return of assets of commercial banks in Nigeria. This finding corroborated with the findings of 
Muia (2017); Mahboub (2018); Adaramola and Kolapo (2019); Akwam and Yua (2021) that mobile payment has significant impact on return on assets of banks, However, Vijayalakshmi and Jayalakshmi (2019); Boateng and Nagaraju, (2020) indicated significant negative impact of mobile payments on return of assets of bank in their studies.

Similarly, the findings of hypothesis three as represented in bound test Table 2 and long relationship model Table 3 indicated that volume of Point-of-Sale (POS) transactions has significant positive impact at the long run. Therefore, null hypothesis is rejected. This finding is corroborated by the findings of Akhisar et al. (2015); $\mathrm{Zu}$ et al. (2019). However, the findings of Abaenewe et al. (2013); Valahzaghard and Bilandi (2014) were in contrast to this finding as the results of their studies indicated that POS have insignificant effect on return of assets of banks.

The results of the findings of hypothesis four as indicated by the ARDL bound test Table 2 and long run relationship model Table 3, indicated that volume of internet have significant impact on return of assets of bank, thus the null hypothesis that volume of internet payment has no significant effect on return on assets of commercial banks in Nigeris is rejected. This finding was in conformity with the findings of Muia (2017); Zu et al. (2019) that internet payment has significant effect on return on assets of banks and in disagreement with the finding of Muotolu and Nwadialor (2019) that volume of internet payment has no significant effect on return of assets of banks.

\section{Conclusion}

This study investigated the effect of payments system innovations on financial performance of commercial banks in Nigeria. To achieve this objective, specifically, it assessed the effect of the volumes of RTGS, mobile payment, POS transactions and internet payment on return on assets of commercial banks in Nigeria. The results indicated that mobile payment, POS transactions and internet payment have positive significant impact on return on assets of commercial banks in Nigeria, while RTGS has negative impact. Therefore, based on these findings it can be concluded that payments system innovations have significant effect on the financial performance of commercial banks in Nigeria.

Based on the findings, this study recommended the need for the commercial banks in Nigeria to increase massive mass media enlightenment campaigns on all payments system innovations/initiatives, in ten dam with the position that increase consumer's patronage of payments system technology with increasing the financial performance of commercial banks in Nigeria. There is also the need for the commercial banks in collaboration with central bank of Nigeria to establish reliable payments system dispute arbitration framework, as that will increase public confidence on the use of the payments system channels, hence increase in financial performance of banks. Also, there is the need for government, corporate organizations, commercial banks in particular, as a matter of necessity pro- 
vide affordable critical infrastructure such as power, access to internet, to enhance performance service delivery to all cities and towns in Nigeria as this will increase consumer's patronage of mobile payment, particularly the unbanked populace in the villages which would ultimately increase financial inclusion.

\section{Conflicts of Interest}

The authors declare no conflicts of interest regarding the publication of this paper.

\section{References}

Abaenewe, Z. C., Ogbulu, O. M., \& Ndugbu, M. O. (2013). Electronic Banking and Bank Performance in Nigeria. West African Journal of Industrial and Academic Research, 6, 171-187.

Adaramola, A. O., \& Kolapo, F. T. (2019). Assessment of Bank Technology Machine and Mobile Banking as Market Strategies to Raising Performance of Banks in Nigeria. Journal of Economics and Behavioral Studies, 11, 108-115. https://doi.org/10.22610/jebs.v11i3(J).2873

Agarwal, S., Khapra M., Uchat N., \& Menezes, B. (2007). Security Issues in Mobile Payment Systems. In Proceedings of the 5th International Conference on E-Governance (pp. 142-152).

Ahrens, T., \& Chapman, C. S. (2006). Doing Qualitative Field Research in Management Accounting: Positioning Data to Contribute to Theory. Handbooks of Management Accounting Research, 1, 299-318. https://doi.org/10.1016/S1751-3243(06)01011-X

Akhisar, I., Tunay, K. B., \& Tunay, N. (2015). The Effects of Innovations on Bank Performance: The Case of Electronic Banking Services. Procedia-Social and Behavioral Sciences, 195, 369-375. https://doi.org/10.1016/j.sbspro.2015.06.336

Akwam, P. O., \& Yua, H. (2021). Effect of Financial Products on the Performance of Selected Deposit Money Banks in Nigeria: 2005-2019. European Journal of Accounting, Auditing and Finance Research, 9, 124-143.

Anselm Ngwa, N. (2020). Electronic Banking Transactions and Their Effects on the Performance of Selected Commercial Banks in Cameroon. Research Journal of Finance and Accounting, 11, 107-115.

Ayodele, T. D. (2014). Electronic banking in Nigeria: Challenges and prospects. Elixir International Journal of Finance management, 69, 22912-22915.

Bingilar, P. F., \& Bariweni, B. (2019). Electronic Payment Systems Implementation and the Performance of Commercial Banks in Nigeria. European Journal of Business and Management Research, 4, 1-5. https://doi.org/10.24018/ejbmr.2019.4.5.112

BIS (Bank for International Settlement) (2006). Committee of Payment and Settlement Systems, General Guidance for National Payments System Development.

BIS (Bank for International Settlement) (2021). Covid-19 Accelerated the Digitalization of Payments. CPMI Red Book Statistics; OECD Main Economic Indicators and $\mathrm{Na}$ tional Accounts.

Boateng, K., \& Nagaraju, Y. (2020). The Impact of Digital Banking on the Profitability of Deposit Money Banks: Evidence from Ghana. International Journal of Research in Finance and Management, 3, 144-150.

CBN (Central Bank of Nigeria) (2013). CBN Briefs 2012-2013 Editor. Central Bank of Nigeria. 
CBN (Central Bank of Nigeria) (2017) CBN Bullion 1976-2016 (Vol. 1-40). Central Bank of Nigeria.

Cherotich, K. M., Sang, W., Mutungú, C., \& Shisia, A. (2015). Financial Innovations and Performance of Commercial Banks in Kenya. International Journal of Economics, Commerce and Management, 3, 1242-1265.

Cirasino, M., \& García, J. A. (2008). Measuring Payment System Development. Payment Systems Policy and Research, Financial Infrastructure Series, World Bank.

Creswell, J. W., \& Creswell, J. D. (2018). Research Design: Qualitative, Quantitative, and Mixed Methods Approaches (5th ed.). Sage Publications.

Davis, F. D. (1989). Perceived Usefulness, Perceived Ease of Use, and User Acceptance of Information Technology. MIS Quarterly, 13, 319-340. https://doi.org/10.2307/249008

Dong, J., Yin, L., Liu, X., Hu, M., Li, X., \& Liu, L. (2020). Impact of Internet Finance on the Performance of Commercial Banks in China. International Review of Financial Analysis, 72, Article ID: 101579. https://doi.org/10.1016/j.irfa.2020.101579

Dormant, D., \& Lee, J. (2011). The Chocolate Model of Change. Lulu. com.

ECB (European Central Banks) (2010). The Payment System. Payments, Securities and derivatives, and the Role of the Eurosystem, 2010. European Central Banks.

Frank, B. P., \& Binaebi, B. (2019). Electronic Payment Systems Implementation and the Performance of Commercial Banks in Nigeria. European Journal of Business and Management Research, 4, Article No. 5. https://doi.org/10.24018/ejbmr.2019.4.5.112

Guo, Y., \& Liang, C. (2016). Blockchain Application and Outlook in the Banking Industry. Financial innovation, 2, Article No. 24. https://doi.org/10.1186/s40854-016-0034-9

Humphrey, D. B., Willesson, M., Bergendahl, G., \& Lindblom, T. (2006). Benefits from a Changing Payment Technology in European Banking. Journal of Banking and Finance, 30, 1631-1652. https://doi.org/10.1016/j.jbankfin.2005.09.009

Ibrahim, U. A. \& Mohammed, Z. (2020). Assessing the Impact of Capital Market Development on Economic Growth: Evidence from Nigeria. IOSR Journal of Economics and Finance, 11, 1-15.

Kamboh, K. M., \& Leghari, M. E. J. (2016). Impact of Cashless Banking on Profitability: A Case Study of Banking Industry of Pakistan. Paradigms, 10, 82-93.

Kelvin, O. (2012). Mobile Money for Financial Inclusion. Journal of Macro Finance, Africa, Nett, Lagos, 4, Article No. 14.

Kerlinger, P., \& Lein, M. R. (1986). Differences in Winter Range among Age-Sex Classes of Snowy Owls Nyctea Scandiaca in North America. Ornis Scandinavica, 17, 1-7. https://doi.org/10.2307/3676745

Lin, B. W. (2007). Information Technology Capability and Value Creation: Evidence from the US Banking Industry. Technology in Society, 29, 93-106. https://doi.org/10.1016/j.techsoc.2006.10.003

Mahboub, R. M. (2018). The Impact of Information and Communication Technology Investments on the Performance of Lebanese Banks. European Research Studies Journal, 21, 435-458. https://doi.org/10.35808/ersj/1133

Malaguti, M. C. (2015). Payment System Regulation for Improving Financial Inclusion. Center for Global Development.

Mertens, D. M. (2019). Research and Evaluation in Education and Psychology: Integrating Diversity with Quantitative, Qualitative, and Mixed Methods. Sage Publications.

Mesagan, E. P., \& Shobande, O. A. (2016). Role of Apex Banks: The Case of Nigerian Economy. Journal of Economics and Business Research, 22, 171-186. 
Moris, F. A. (1996). Semiconductors: The Building Block of the Information Revolution. Monthly Labor Review, 119, 6-17.

Morufu, O. (2016). E-Payments Adoption and Profitability Performance of Deposits Money Banks in Nigeria. IPASJ International Journal of Information Technology, 4, 1-9.

Muhoro, D. I., \& Mungai, J. (2018). Real Time Gross Settlement and Financial Performance of Commercial Banks in Kenya. International Academic Journal of Economics and Finance, 3, 110-122.

Muia, S. W. (2017). The Effect of Financial Innovations on Financial Performance of Commercial Banks in Kenya. Doctoral Dissertation, Kca University. http://41.89.49.13:8080/xmlui/handle/123456789/1243

Muisyo, J. M., Alala, O., \& Musiega, D. (2014). The Effects of Mobile Money Services on the Performance of the Banking Institutions: A Case of Kakamega Town. Transactions, 354(16,700,000), 4-600.

Muotolu, P. C., \& Nwadialor, E. O. (2019). Cashless Policy and Financial Performance of Deposit Money Banks in Nigeria. International Journal of Trend in Scientific Research and Development, 3, 465-476. https://doi.org/10.31142/ijtsrd23835

Nwakoby, N. P., Okoye, J. N., Ezejiofor, R. A., Anukwu, C. C., \& Ihediwa, A. (2020). Electronic Banking and Profitability: Empirical Evidence from Selected Banks in Nigeria. Journal of Economics and Business, 3, 637-649. https://doi.org/10.31014/aior.1992.03.02.227

Nwankwo, O., \& Eze, O. R. (2013). Electronic Payment in Cashless Economy of Nigeria: Problems and Prospect. Journal of Management Research, 5, 138-151. https://doi.org/10.5296/jmr.v5i1.2650

Nwankwo, S. N., \& Agbo, E. I. (2021). Effects of Electronic Banking on Commercial Bank Performance in Nigeria. European Journal of Accounting, Finance and Investment, 7 , 68-81.

Okafor, C. A. (2020). Cashless Policy for Business Purpose and the Performance of Deposit Money Banks in Nigeria. International Journal of Innovative Finance and Economics Research, $8,1-13$.

Onay, C., \& Ozsoz, E. (2013). The Impact of Internet-Banking on Brick and Mortar Branches: The Case of Turkey. Journal of Financial Services Research, 44, 187-204. https://doi.org/10.1007/s10693-011-0124-9

Orji, A., Ogbuabor, J. E., Okon, A. N., \& Anthony-Orji, O. I. (2018). Electronic Banking Innovations and Selected Banks Performance in Nigeria. The Economics and Finance Letters, 5, 46-57. https://doi.org/10.18488/journal.29.2018.52.46.57

Osang, F. B. (2017) E-Banking: Evaluating Electronic Payment Channels in Southern Nigeria. NOUN Journal of Physical and Life Sciences, 1, 135-157.

Phillips, D. C., \& Burbules, N. C. (2000). Postpositivism and Educational Research. Rowman \& Littlefield.

Rogers, G. F. C. (1983). The Nature of Engineering: A Philosophy of Technology. Macmillan International Higher Education. https://doi.org/10.1007/978-1-349-06683-4_6

Rogers, E. M. (1962, 2003). Diffusion of Innovations (5th ed.). Free Press.

Saeed, K. A., \& Bampton, R. (2013). The Impact of Information and Communication Technology on the Performance of Libyan Banks. Journal of WEI Business and Economics-December, 2, 21-26.

Salehi, M., \& Alipour, H. (2014). Customer Satisfaction Measurement at Kerman Saderat Bank by Using of QFD Method to Improve Service Quality. Indian Journal of Fundamental and Applied Life Sciences, 5, 1664-1670. 
Shahabi, V., \& Razi, F. F. (2019). Modeling the Effect of Electronic Banking Expansion on Profitability Using Neural Networks and System Dynamics Approach. Qualitative Research in Financial Markets, 11, 197-210. https://doi.org/10.1108/QRFM-11-2018-0117

Shanmugam, K. R., \& Nigam, R. (2020). Impact of Technology on the Financial Performance of Indian Commercial Banks: A Clustering Based Approach. Innovation and Development, 10, 433-449. https://doi.org/10.1080/2157930X.2019.1685792

Straub, E. T. (2009). Understanding Technology Adoption: Theory and Future Directions for Informal Learning. Review of Educational Research, 79, 625-649. https://doi.org/10.3102/0034654308325896

Suleymanov, Q., Farzaliyev, M., \& Nagiyev, M. (2019). The Effects of Innovations on Bank Performance: The Case of Electronic Banking Services. Recent Trends in Science and Technology Management, No. 2, 20-29.

Summers, B. J. (2012). Payment Systems-Design, Governance and Oversight. Central Banking Publications.

Tasaki, T., \& Yamakawa, H. (2011). An Estimation of the Effectiveness of Waste Prevention by Using Point-of-Sales (POS) Data-The Case of Refills for Shampoo and Hair Conditioner in Japan. Resources, Conservation and Recycling, 57, 61-66.

https://doi.org/10.1016/j.resconrec.2011.09.019

Taylor, E. (2013). Staying Ahead of the Game. Mobile Technologies in Retail: A Review of Benefits and Risk (pp. 8-9). Efficient Consumer Response Australasia (ECRA) Loss Prevention Group.

Tran, M. H. (2021). Payment System and Bank Performance: Evidence from Vietnam. Journal of Contemporary Issues in Business and Government, 27, 91-94.

Tunay, K. B., Tunay, N., \& Akhisar, I. (2015). Interaction between Internet Banking and Bank Performance: The Case of Europe. Procedia-Social and Behavioral Sciences, 195, 363-368. https://doi.org/10.1016/j.sbspro.2015.06.335

Valahzaghard, M., \& Bilandi, E. (2014). The Impact of Electronic Banking on Profitability and Market Share: Evidence from Banking Industry. Management Science Letters, 4, 2531-2536. https://doi.org/10.5267/j.msl.2014.11.003

Vekya, J. M. (2017). Impact of Electronic Banking on the Profitability of Commercial Banks in Kenya. Journal of Technology and Systems, 1, 18-39.

Vijayalakshmi, B., \& Jayalakshmi, M. (2019). A Study on Digital Transactions Impact on Financial Performance of Banking Sector with Reference to SBI and ICICI. Journal of Internet Banking and Commerce, 24, 1-13.

Vikram, S. K., \& Gayathri, G. (2018). Impact of Information Technology on the Profitability of Banks in India. International Journal of Pure and Applied Mathematics, 118, 225-232.

WBG (World Bank Group) (2018). Payments System Worldwide: A Snap Short, Summary Outcomes of Fourth Global Payment Systems Survey. World Bank Group.

Yao, M., Di, H., Zheng, X., \& Xu, X. (2018). Impact of Payment Technology Innovations on the Traditional Financial Industry: A Focus on China. Technological Forecasting and Social Change, 135, 199-207. https://doi.org/10.1016/j.techfore.2017.12.023

Yusuf, A. I., Oke, O. B., \& Ezike, J. E. (2019). E-Payment Technology Channels and Performance of Deposit Money Banks: Evidence from Nigeria. International Journal of Intelligent Technologies \& Applied Statistics, 12, 219-220.

Zu, J., Gu, Y., Li, K., \& Bonsu, O. A. M. (2019). Impacts of Financial Innovations on Financial Performance Evidence of Electronic Banking in Africa. Methodology, 3, 56-60. 